\title{
STRUCTURAL SUSTAINABILITY OF CAMBISOL UNDER DIFFERENT LAND USE SYSTE ${ }^{(1)}$
}

\author{
Paula Cristina Caruana Martins ${ }^{(2)}$, Moacir de Souza Dias J uni or ${ }^{(3)}$, Ayodele E benezer \\ Ajayi $^{(4)}$ \& Fátima Maria de Souza Moreira(5)
}

\begin{abstract}
SUMMARY
Incongruous management techniques have been associated with some significant loss of agricultural land to degradation in many parts of the world. Land degradation results in the alteration of physical, chemical and biological properties of the soil, thereby posing a serious threat to sustainable agricultural development. In this study, our objective is to evaluate the changes in a Cambisol structure under six land use systems using the load bearing capacity model. Sampling was conducted in Amazonas Region, Brazil, in the following land use: a) young secondary forest; $b$ ) old secondary forest; c) forest; d) pasture; e) cropping, and f) agroforestry. To obtain the load bearing capacity models the undisturbed soil samples were collected in those land use systems and subjected to the uniaxial compression test. These models were used to evaluate which land use system preserved or degraded the Cambisol structure. The results of the bulk density and total porosity of the soil samples were not adequate to quantify structural degradation in Cambisol. Using the forest topsoil level $(0-0.03 \mathrm{~m})$ as a reference, it was observed that pasture land use system was most severe in the degradation of the soil structure whi le the structure were most preserved under old secondary forest, cropping system and forest. At the subsoil level (0.10-0.13 m depth), the soil structure was most degraded in the cropping land use system while it was most preserved in young secondary forest and pasture. At the 0.20-0.23 m depth, soil structure degradation was most severe in the old secondary forest system and well preserved in young secondary forest, cropping and agroforestry.
\end{abstract}

Index terms: structure degradation, bulk density, precompression stress, Amazonas.

\footnotetext{
(1) Parte da Tese de Mestrado do primeiro autor apresentada ao Programa de Pós-Graduação em Ciência do Solo do Departamento de Ciência do Solo da Universidade Federal de Lavras - DCS/UFLA. Received for publication in September 6, 2011 and approved in September 4, 2012.

(2) Eng.-Agrônoma, Doutoranda do DCS/UFLA Bolsista do CNPq. Campus Universitário UFLA, s/n. I nácio Valetim. CEP 37200000 Lavras (MG). E-mail: pccaruana@hotmail.com

(3) Eng. Agrícola, Ph.D em Crop and Soil Science, Professor Associado, DCS/UFLA Bolsista CNPq e Pesquisador Mineiro FAPEMIG. E-mail: msouzadj@dcs.ufla.br

(4) Professor, Soil, Water and Environment Section, Department of Agricultural Engineering, Federal University of Technology, PMB 704, Akure, Ondo State, (Nigeria). E-mail: ayo.ajayi@gmail.com

(5) Professora Associado, DCS/UFLA. Bolsista do CNPq. E-mail: fmoreira@dcs.ufla.br
} 


\title{
RESUMO: SUSTENTABILIDADE ESTRUTURAL DE UM CAMBISSOLO SOB DIFERENTES SISTEMAS DE USO
}

\begin{abstract}
Técnicas inadequadas de manejo têm sido associadas com a degradação de terras agricultáveis em muitas partes do mundo. A degradação do sol o resulta em al terações das propriedades físicas, químicas e biológicas do solo, o que representa séria ameaça ao desenvol vimento agrícol a sustentável. O objetivo deste estudo foi avaliar as alterações da estrutura deum Cambissolo sob seissistemas deuso da terra por méo dos model os decapacidade desuportedecarga. A amostragem foi realizada na região Amazônica, Brasil , nos seguintes sistemas deuso: a) floresta secundária nova; b) floresta secundária vel ha; c) floresta; d) pastagem; e) roça; ef) agr ofl oresta. Para obter os model os decapacidadedesuportedecarga, as amostras indeformadas foram coletadas nesses sistemas de uso da terra esubmetidas ao ensaio de compressão uniaxial. Esses model os foram usados para aval iar qual sistema deuso da terra preserva ou degrada a estrutura do Cambissolo. Os resultados da densi dadedo sol oeporosidade total do sol o não foram adequados para quantificar a degradação estrutural do Cambissol o. Utilizando a profundidadede0-0,03 m da floresta como referência, observou-sequea pastagem foi o sistema deuso da terra quemais promoveu degradação da estrutura do sol o, ao passo que a estrutura foi mais preservada na floresta secundária vel ha, roça efloresta. Na profundidade de 0,10-0,13 m, a estrutura do solo foi mais degradada no sistema de cultivo roça e mais preservada na floresta secundária jovem e pastagem. Na profundidade de 0,20-0,23 m, a degradação da estrutura do sol o foi mais intensa na floresta secundária vel ha emais preservada na floresta secundária nova, roça eagrofl oresta.
\end{abstract}

Termos deindexação: degradação da estrutura, densi dadedo sol o, pressão depréconsolidação, Amazonas.

\section{INTRODUCTION}

Theappropriatemanagement of land resources is critical to sustainableagricultural production, as its inappropriate use could result in thealteration of the physical, chemical and biological properties of the soil thereby promoting degradation. It is therefore imperative to evolve a strategic land use and management systems and system mixes that would promote efficient utilization of this limited resource by preserving its structure and thereby prevent degradation and attendant compaction.

There been concerted efforts in the literature to investigate the effect of different land use system and management practices on soil physical, mechanical, hydrological and chemical and sometimes engineering properties (Silva et al., 2006; DiasJ unior et al., 2007; AraujoJ unior et al., 2008; Glab \& Kulig, 2008). Most of these studies have been premised on the investigation of theindexes of structural sustainability or degradation. Someland useand soil management system havebeen reported to causesignificant increase in bulk density and mechanical strength of soils (Taylor, 1971; Glab \& Kulig, 2008; Abid \& Lal, 2008; Severiano et al., 2008); decreasein total porosity, pore size and continuity of pores in soils (Glab \& Kulig, 2008; Severiano et al., 2008), reduction in soil's nutrient absorption, infiltration and redistribution of water (Arvidsson, 2001; I shaq et al., 2001; Li piec et al., 2006), reduction of hydraulic conductivity (Arvidsson, 2001; Silva et al., 2006), reduction of gas exchange (Gysi, 2001) and increase in the soil's load bearing capacity and compactibility (Dias J unior et al., 2007; Silva et al., 2007; AraujoJ unior et al., 2008; DiasJ unior et al., 2008).

In Brazil agricultural system, the study of soil compaction which has the most degenerative effect on soil structure has been hinged mainly on the determination of precompression stress. The precompression stress separates the region of recoverable deformation from the non-recoverable deformation and thereby defines the point where soil structure degradation may occur (Silva et al., 1999; Dias J unior \& Pierce, 1996; Silva et al., 2007; Severianoet al., 2008; Ajayi et al., 2010; Severiano et al., 2010a,b; Araujo J unior et al., 2011; Pacheco \& Cantalice, 2011; F igueir redo et al., 2011). It has been used as a parameter to evaluatethesusceptibility and vulnerability of soil structure to compaction under varying management scenarios ( $\mathrm{J}$ ones et al., 2003; Spoor et al., 2003; Arvidsson \& Keller 2004; Ajayi et al., 2010). Since it has been established that soil structure degradation may occur at any moisture content (Dias J unior \& Pierce, 1995), it is important that any study designed to monitor soil structural changes must measure soil properties that would highlight these deformations at various moisturelevel.

Reviewing thepublished studies on Brazilian and some other sub-tropical regions agriculture systems, it was noted that thereare very few studies that takes intoaccount, themeasurement of soil precompression stress as a function of water content to diagnose changes in soil structure for the different land use system. Considering the rate of development of 
mechanized agriculture in the Amazon Region of Brazil due to the productive nature of Cambisol soil widely found in the region, this study was designed with the objective of evaluating the changes in a Cambisol structure under six different land use systems using theload bearing capacity model.

\section{MATERIAL AND METHODS}

Soil samples were collected in the Benjamin Constant County $\left(4^{\circ} 26^{\prime} \mathrm{S}\right.$ and $\left.69^{\circ} 36^{\prime} \mathrm{W}\right)$, North Western State of Amazon. This region commonly referred to as the Upper Amazon lies within the triangular border between Brazil, Col ombia and Peru. The dominant soil class in the region is Cambisol (Ustox) (Coel hoet al., 2005). The climate of theupper Amazon, by the criteria of Köppen, is tropical humid or super humid (Af), with no significant dry season and an annual averagetemperature of $25.7^{\circ} \mathrm{C}$. Mean annual rainfall is $2,562 \mathrm{~mm}$. Thetotal rainfall of the driest month is greater than $100 \mathrm{~mm}$, with higher rainfall concentrated in the months from December to April (Coelho et al., 2005).

The studied area represents a discontinuous surface of approximately $218,400 \mathrm{~m}^{2}$ and was divided into six windows for standardized sampling under the project Biosbrasil (http://vsites.unb.br/ib/zoo/bios/ indexe.html). The windows were also selected to ensure that the practices arevery similar in each the identified land use systems, indicating there are no accentuated differences in terms of intensity of use in each system. The approximate area of each window is 3.64 ha, divided into $100 \times 100 / 50$ m sampling grids. These windows were divided tor eflect the various land use system and the dominant soil types (Fidalgo et al., 2005). The predominant land use systems in agricultural production system in thestudy area are based on a cycle of deforestation and burning of secondary vegetation to grow crops over a given period. In some instances, agroforestry resulting from the spontaneous regeneration of secondary forest species is practiced. Interviews with farmers in the region revealed that most of the areas used in agroforestry systems were deforested between 1979 and 1983 and were planted with banana and cassava. The use for agroforestry began soon after the first few cycles of cultivation, between 1980 and 1984 (Fidalgo et al., 2005). The secondary forest system was further divided into young secondary forest and ol d secondary forest according to their stage of regeneration.

Thus, within the scope of this study ${ }^{(6)}$, the land usesystem are classified as forest - areas with original forest type, with no evidence of the removal of timber
(Windows 1 and 4); old secondary forest - includes secondary forest areas in advanced stages of regeneration with morethan five years of formation after being used for cropping (Windows 3, 4 and 5); young secondary forest - includes secondary forest areas in early stages of regeneration with less than five years of formation after being cropped (Windows 2, 3, 4 and 5); agroforestry - includes areas where much of the vegetation is formed by the spontaneous regeneration of secondary forest species and is also planted to annual crops for economic interests (Windows 2 and 5); cropping - includes areas planted to annual crops (cassava, maize, sugarcane and pineapple) and perennial crop (banana) (Windows 2, 3, 4.5 and 6); and pasture-includes areas for livestock production, covered by grasses (Window 6). Theseland use systems were compared using the load bearing capacity models to identify which one preserves or degrades the Cambisol structure.

To obtain the load bearing capacity models, in March 2008, undisturbed soil samples were collected at depths 0-0.03, 0.10-0.13, and 0.20-0.23 m from field within the different six land use systems. In each land use system, 10 undisturbed soil samples werecollected in $6.5 \times 2.5 \mathrm{~cm}$ aluminum rings, using Uhland undisturbed soil sampler. The sampling device was pushed carefully into the soil using a falling weight. Thus a total of 180 samples were collected i.e. (six land use systems $x$ three depths $x 10$ samples per depth). At each point of sample collection, the ring filled with soil was removed from theU hland sampler, and wrapped with plastic materials and paraffin wax until uniaxial compression tests wereperformed.

In the laboratory, the soil samples were carefully trimmed to the size of their respective rings, whose inner diameter, height and weight had been premeasured. This was used to determinetheinitial field bulk density of each sample. The disturbed soil samples scraped near the intact soil cores were airdried and passed through a $2 \mathrm{~mm}$ sieveand stored in plastic bags prior to other analyses. Basic soil characterization of the samples was performed according to Brazilian standard procedures as described in Embrapa (2006). Partide-size-distribution was determined using the pipette method after dispersing with 1 mol L-1 NaOH (Day, 1986) (Table 1). Particle density was determined using $95 \%$ hydrated al cohol with $20 \mathrm{~g}$ of air-dried soil material in a $50 \mathrm{~mL}$ pycnometer (Blake\& Hartge, 1986b). The total porosity (TP) was cal culated from theexpression:

$$
\mathrm{TP}=\left(1-\frac{\mathrm{BD}}{\mathrm{PD}}\right)
$$

where DB is bulk density $\left(\mathrm{Mg} \mathrm{m}^{-3}\right)$ and PD is particle density $\left(\mathrm{Mg} \mathrm{m}^{-3}\right)$.

\footnotetext{
(6) Project BiosBrasil/Conservation and sustainable management of below ground biodiversity (CSM-BGBD) implemented by the Global Environment Facility of the "United Nations Program (UNEP)" and executed in seven countries: Brazil, Ivory Coast, India, Indonesia, Kenya, Mexico and Uganda. In Brazil, GF2715/02.
} 
For the uniaxial compression test, some prepared soil cores samples held in thealuminum rings, from each land use system and at the various depths, were initially saturated in a tray filled with water up to $2 / 3$ of the samples height, for $24 \mathrm{~h}$. The saturated samples were later air-dried in thelaboratory to obtain the water content levels between 0.28 to $0.66 \mathrm{~m}^{3} \mathrm{~m}^{-3}$ and then subjected to uniaxial compression test (Bowles, 1986) using a Boart L ongyear consolidometer in which the pressures were applied by compressed air. For the test, the undisturbed soil samples were kept within the coring cylinders, which were placed into the compression cell, and afterward submitted to pressures of $25,50,100,200,400,800$ and 1,600 kPa. Each pressure was applied until $90 \%$ of themaximum deformation was reached (Taylor, 1948) and then the pressure was increased to thenext level following the procedures described in Dias] unior \& Pierce, (1995) and Dias J unior et al. (2008).

The precompression stress $\left(s_{p}\right)$ for each of the samples were obtained from the corresponding soil compression curves constructed from the applied stress versus bulk density data (Dias) unior \& Pierce, 1995; Ajayi et al., 2010). The precompression stresses were thereafter plotted as a function of volumetric water content. Regression analyzes were performed to obtain themathematical equations that corresponds totheload bearing capacity model susing the software Sigma Plot 8.0 (Sigma Plot, 2002) and comparisons of the regression lines were performed using the procedure described in Snedecor \& Cochran (1989). Theresults of thebulk density (Blake\& Hartge, 1986a) and total porosity (Table1) wereanalyzed for variance and comparison of means was implemented with ScottKnott $(p \varangle 0,05)$ procedure.

\section{RESULTS AND DISCUSSION}

The particle size distribution, silt/clay ratio and textural classes of the Cambisol at different depths and land use systems are presented in table 1. The high silt/clay ratio is peculiar for this soil class and this trend is maintained in almost all the different land use systems. The variability of this ratio is in agreement with thelow pedogenic devel opment of the Cambisol class (Kämpf \& Curi, 2012).

The values of theinitial field bulk density and total porosity (Table1) did not differ among thesix different land usesystems and in the various depths considered in this study. This indicates that bulk density and total porosity may not be appropriate to accentuate the effect of the various land use systems on the Cambisol structure. These results agree with that of Martins (2009) which concluded that not all variation in the initial bulk density and total porosity may not besufficient as indexes of soil structure degradation. However, it should be noted, that the insignificance in the variation of the initial bulk density does not imply that there is no soil structure deformation as a consequence of the various land use systems, rather it implied that most of the deformations occur within the region of the secondary compression curve, wherein they would be elastic and recoverable (Figure 1); suggesting that changes in these properties will not be adequate to characterize the soil structure degradation. Degradation of soil structure occurs only when the deformation (inducing variations in these properties) occur within the region of plastic deformation, wherein the deformations are not recoverable, being bounded by preconsolidation pressure. From that initial observation, it was concluded that soil structure degradation in this study would be analyzed using the load bearing capacity models (a variation of precompression stress against moisture content) of the soil samples at the various depths under the different land use systems.

It was observed that for the three depths and different land use systems considered, the precompression stress $\left(\sigma_{p}\right)$ decreases exponentially with volumetric water content $(\theta)$, as si milarly observed in previous other studies (Mosaddeghi et al., 2003; Peng et al., 2004; Severiano et al., 2009; Ajayi et al., 2011). Using the model proposed by Dias J unior \& Pierce (1995) $\sigma_{p}=10^{(a+b \theta)}$, where $\sigma_{p}$ is the precompression stress, "a" and "b" are empirical parameters of the adjustment of the model, and $\theta$ is the vol umetric water content; representative load bearing capacity models for the different land usesystems for thevarious depth were constructed (Figures 2 to 4 ).

At 0-0.03 m depth, when compared, the load bearing capacity models for old secondary forest, cropping and forest were not statistically different. Similarly theload bearing capacity model of theyoung secondary forest and agroforestry were not different (Table 2). In the land use systems that were not statistically different, a single equation was then fitted to all values of precompression stress and volumetric water content, therefore generating a single and representativeload bearing capacity model for these mixes of land use systems (Figure 2).

Using theload bearing capacity model of theforest land use system as a reference for structural preservation at the 0-0.03 m depth (Figure 2 ), it was observed that, at any water content, the pastureland usesystem had thehighest bearing capacity indicating a deterioration of the Cambisol structureat this depth due to cattle trampling. This corroborates the conclusions of Muller et al. (2001) and Correa \& Reicherdt (1995) on the effect of animal trampling on soil structure in the topsoil zone. At this depth, the old secondary forest, cropping and forest land use systems were observed to preserve the Cambisol structure. It is noteworthy that the more preserved the soil structureis, the more susceptible it is, to soil compaction, due to its lower bearing capacity. The higher susceptibility to compaction of these land use 
Table 1. Particlesize distribution, silt/clay ratio, textural classes and physical characteristics of the Cambisol samples at three depths under different land use systems

\begin{tabular}{|c|c|c|c|c|c|c|c|c|}
\hline Land use system & Sand $^{(\mathbf{1})}$ & Silt & Clay & Silt/Clay & Textural class & $B D i^{(2)}$ & $\mathbf{P D}^{(1)}$ & $\operatorname{TP}^{(2)}$ \\
\hline & \multirow{2}{*}{\multicolumn{4}{|c|}{$-\mathrm{g} \mathrm{kg}^{-1}$}} & & \multicolumn{2}{|c|}{$\mathrm{Mg} \mathrm{m}^{-3}$} & $m^{3} m^{-3}$ \\
\hline & & & & & $0-0.03 \mathrm{~m}$ & & & \\
\hline Young secondary forest & 170 & 520 & 310 & 1.68 & Silty clay loam & $1.09 \mathrm{a}$ & $2.44 \mathrm{c}$ & $0.55 a$ \\
\hline Old secondary forest & 300 & 410 & 290 & 1.41 & Clay loam & $1.15 \mathrm{a}$ & $2.50 \mathrm{a}$ & $0.54 a$ \\
\hline Forest & 150 & 540 & 310 & 1.74 & Silty clay loam & $1.06 \mathrm{a}$ & $2.41 \mathrm{~d}$ & $0.56 \mathrm{a}$ \\
\hline Pasture & 460 & 320 & 220 & 1.45 & Loam & $1.04 \mathrm{a}$ & $2.44 \mathrm{c}$ & $0.57 \mathrm{a}$ \\
\hline Cropping & 270 & 250 & 480 & 0.52 & Clay & $1.02 \mathrm{a}$ & $2.44 \mathrm{c}$ & $0.58 \mathrm{a}$ \\
\hline \multirow[t]{2}{*}{ Agroforestry } & 170 & 470 & 360 & 1.31 & Silty clay loam & $1.07 \mathrm{a}$ & $2.47 \mathrm{~b}$ & $0.57 \mathrm{a}$ \\
\hline & & & & & $0.10-0.13 \mathrm{~m}$ & & & \\
\hline Young secondary forest & 240 & 370 & 390 & 0.95 & Clay Ioam & $1.23 \mathrm{a}$ & $2.53 b$ & $0.51 \mathrm{a}$ \\
\hline Old secondary forest & 180 & 440 & 380 & 1.16 & Clay loam & $1.26 \mathrm{a}$ & $2.53 b$ & $0.50 \mathrm{a}$ \\
\hline Forest & 200 & 450 & 350 & 1.29 & Clay loam & $1.23 \mathrm{a}$ & $2.53 b$ & $0.51 \mathrm{a}$ \\
\hline Pasture & 160 & 440 & 400 & 1.10 & Clay & $1.20 \mathrm{a}$ & $2.41 c$ & $0.50 \mathrm{a}$ \\
\hline Cropping & 160 & 440 & 400 & 1.10 & Clay & $1.23 \mathrm{a}$ & $2.56 a$ & $0.52 \mathrm{a}$ \\
\hline \multirow[t]{2}{*}{ Agroforestry } & 120 & 430 & 450 & 0.96 & Silty clay & $1.27 \mathrm{a}$ & $2.41 c$ & $0.47 a$ \\
\hline & & & & & $0.20-0.23 \mathrm{~m}$ & & & \\
\hline Young secondary forest & 160 & 470 & 370 & 1.27 & Silty clay loam & $1.30 \mathrm{a}$ & $2.50 \mathrm{c}$ & $0.48 a$ \\
\hline Old secondary forest & 160 & 410 & 430 & 0.95 & Clay & $1.23 \mathrm{a}$ & $2.56 \mathrm{~b}$ & $0.52 \mathrm{a}$ \\
\hline Forest & 180 & 380 & 440 & 0.86 & Clay & $1.28 \mathrm{a}$ & $2.60 \mathrm{a}$ & $0.51 \mathrm{a}$ \\
\hline Pasture & 320 & 370 & 310 & 1.19 & Clay loam & $1.26 \mathrm{a}$ & $2.50 \mathrm{c}$ & $0.50 a$ \\
\hline Cropping & 80 & 440 & 480 & 0.92 & Silty clay & $1.28 \mathrm{a}$ & $2.60 \mathrm{a}$ & $0.51 \mathrm{a}$ \\
\hline Agroforestry & 150 & 330 & 520 & 0.63 & Clay & $1.24 \mathrm{a}$ & $2.50 \mathrm{c}$ & $0.50 \mathrm{a}$ \\
\hline
\end{tabular}

(1) and ${ }^{(2)}$ : Average of three and 10 replications, respectively, BDi: Initial bulk density; PD: particle density; TP: total porosity. Average in columns and the same depth with the same letter did not differ by Scott-Knott at $5 \%$.

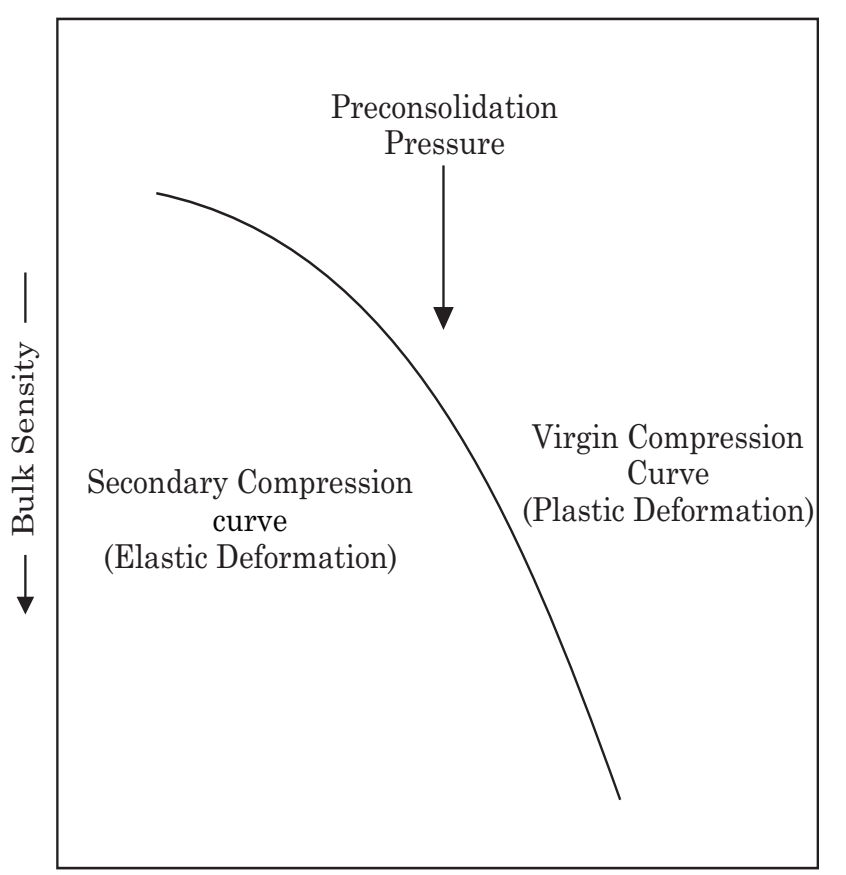

Log Applied Pressure $\longrightarrow$

Figure 1. Soil compression curve. systems may be related to the formation of biopores and thesteady incorporation of organic matter from the decomposition of roots and leaves (Muller et al., 2001, 2004). Similarly, the loosening of soil particles duringtillage operations is significant at this depth (Arkin \& Taylor, 1981).

For the 0.10-0.13 $\mathrm{m}$ depth, the load bearing capacity models for young secondary forest and pasture were not different. Those of the ol d secondary forest and forest land use systems were al so not different (Table 2). Therefore the respective data were of the land use systems that were not statistically different were fitted with a singl e equation generating a single load bearing capacity model for theseland usesystems (Figure 3).

The result showed that at $0.10-0.13 \mathrm{~m}$ depth, cropping was found to degrademost the soil structure, whileyoung secondary for est and pasture preserved thesoil structure(Figure3). The high bearing capacity of the cropping land use system is indicative of the Cambisol structure degradation that may have been induced by the hard pan created by tillage implement used in initial land preparation (Arkin \& Taylor, 1981). Thelower bearing capacity presented by young secondary forest and pasture may be indicative of a 
Table 2. Comparison of the load bearing capacity models(1) $\left[\sigma_{p}=10(a+b \theta)\right]$ of a Cambisol samples for different land use systems at $0-0.03,0.10-0.13$ and $0.20-0.23$ m depths

Land use system Homogeneity Intercept “a” Slope "b"

Old secondary forest $x$ cropping $0-0.03 \mathrm{~m}$

Old secondary forest and cropping $x$ forest

Old secondary forest, cropping and forest $x$ young secondary forest

Old secondary forest, cropping and forest $x$ agroforestry

Old secondary forest, cropping and forest $x$ pasture

Young secondary forest $x$ agroforestry

Young secondary forest and agroforestry $x$ pasture

Young secondary forest and agroforestry $\mathrm{x}$ old secondary forest, cropping and forest

Young secondary forest $x$ pasture

Young secondary forest and pasture $x$ agroforestry

Young secondary forest and pasture $x$ old secondary forest

Young secondary forest and pasture $x$ forest

Young secondary forest and pasture $x$ cropping

Old secondary forest $x$ forest

Young secondary forest and pasture $x$ old secondary forest and forest

Old secondary forest and forest $x$ cropping

Old secondary forest and forest $x$ agroforestry

Cropping $x$ agroforestry

Forest $x$ pasture

Forest and pasture $x$ old secondary forest

Forest and pasture $x$ cropping

Forest and pasture $x$ young secondary forest

Forest and pasture $x$ agroforestry

Young secondary forest $x$ old secondary forest

Old secondary forest $x$ cropping

Old secondary forest $x$ agroforestry

Young secondary forest $x$ cropping

Young secondary forest $x$ agroforestry

Cropping $x$ agroforestry

\begin{tabular}{|c|c|c|}
\hline $\mathrm{H}$ & ns & ns \\
\hline $\mathrm{H}$ & ns & ns \\
\hline $\mathrm{H}$ & $*$ & $* *$ \\
\hline $\mathrm{H}$ & $* *$ & $* *$ \\
\hline $\mathrm{H}$ & $* *$ & $* *$ \\
\hline $\mathrm{H}$ & ns & ns \\
\hline $\mathrm{H}$ & $* *$ & ns \\
\hline \multirow[t]{2}{*}{$\mathrm{H}$} & $* *$ & $* *$ \\
\hline & $0.10-0.30 m$ & \\
\hline $\mathrm{H}$ & ns & ns \\
\hline $\mathrm{H}$ & $*$ & ns \\
\hline $\mathrm{H}$ & $* *$ & ns \\
\hline $\mathrm{H}$ & $* *$ & ns \\
\hline $\mathrm{H}$ & $* *$ & $* *$ \\
\hline $\mathrm{H}$ & ns & ns \\
\hline $\mathrm{H}$ & $* *$ & ns \\
\hline $\mathrm{H}$ & ns & $* *$ \\
\hline $\mathrm{H}$ & $* *$ & ns \\
\hline \multirow[t]{2}{*}{$\mathrm{H}$} & ** & $* *$ \\
\hline & $0.20-0.23 \mathrm{~m}$ & \\
\hline $\mathrm{H}$ & ns & ns \\
\hline $\mathrm{H}$ & $* *$ & $* *$ \\
\hline $\mathrm{H}$ & ns & $* *$ \\
\hline $\mathrm{H}$ & $* *$ & $* *$ \\
\hline $\mathrm{H}$ & $* *$ & $* *$ \\
\hline $\mathrm{H}$ & $* *$ & $* *$ \\
\hline $\mathrm{H}$ & $* *$ & $* *$ \\
\hline $\mathrm{H}$ & $* *$ & ns \\
\hline $\mathrm{H}$ & ns & $* *$ \\
\hline $\mathrm{H}$ & ns & $* *$ \\
\hline $\mathrm{H}$ & ns & $* *$ \\
\hline
\end{tabular}

(1) According described in Snedecor \& Cochran (1989). H: Homogeneous, *and **: F test significant at 5 and $1 \%$ level, respectively; ns: not significant.

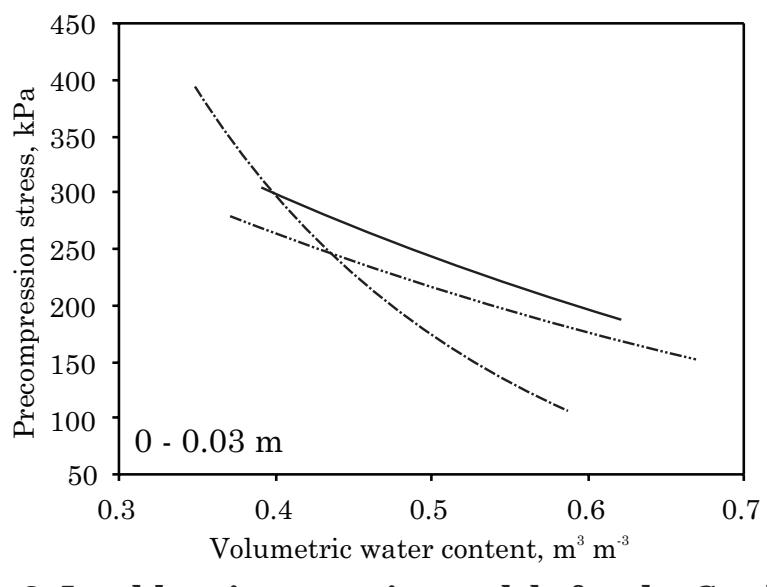

$$
\begin{aligned}
& \text { - Pasture: } \\
& \sigma_{\mathrm{p}}=10^{(2.84-0.91 \theta)} \mathrm{R}^{2}=0.83^{* *} \quad(\mathrm{n}=10)
\end{aligned}
$$

Figure 2. Load bearing capacity models for the Cambisol at $\mathbf{0}-0.03 \mathrm{~m}$ depth under different land use systems. 
recovery of the Cambisol structure due to formation of biopores and organic matter incorporation from decomposing roots associated with these land use systems (Muller et al., 2001, 2004).

A comparison of the precompression stress data for the various land use systems at 0.20-0.23 m depth indicated that the load bearing capacity models for forest and pastureland usesystems werenot different (Table2). Thus, a representativeload bearing capacity model was generated for these mix of land use systems (Figure4).

It was observed that at 0.20-0.23 m depth, the old secondary for est land use system degraded most the Cambisol structure, whiletheyoung secondary forest, cropping and agroforestry systems preserved the soil structure. The observed degradation in this layer by theold secondary forest may berelated tothe natural consolidation of the Cambisol structureassociated with compression of the soil by thick roots that is trying to occupy thespaces previously occupied by air and water when the soil was deforested (Arkin \& Taylor, 1981; Araújo et al., 2004). I t was observed that the extent of degradation of the soil is related to the stage of regeneration of the secondary forest.

\section{CONCLUSIONS}

1. Theresults of thebulk density and total porosity of the soil samples were not adequate to quantify structural degradation in Cambisol.

2. Using the forest topsoil level $(0-0.03 \mathrm{~m})$ as a reference, it was observed that pastureland use system was most severe in the degradation of the soil structure while the structure were most preserved under old secondary forest, cropping system and forest.

3. At the subsoil level (0.10-0.13 m depth), the soil structure was most degraded in thecropping land use system while it was most preserved in young secondary forest and pasture.

4. At the 0.20-0.23 m depth, soil structure degradation was most severein theold secondary forest

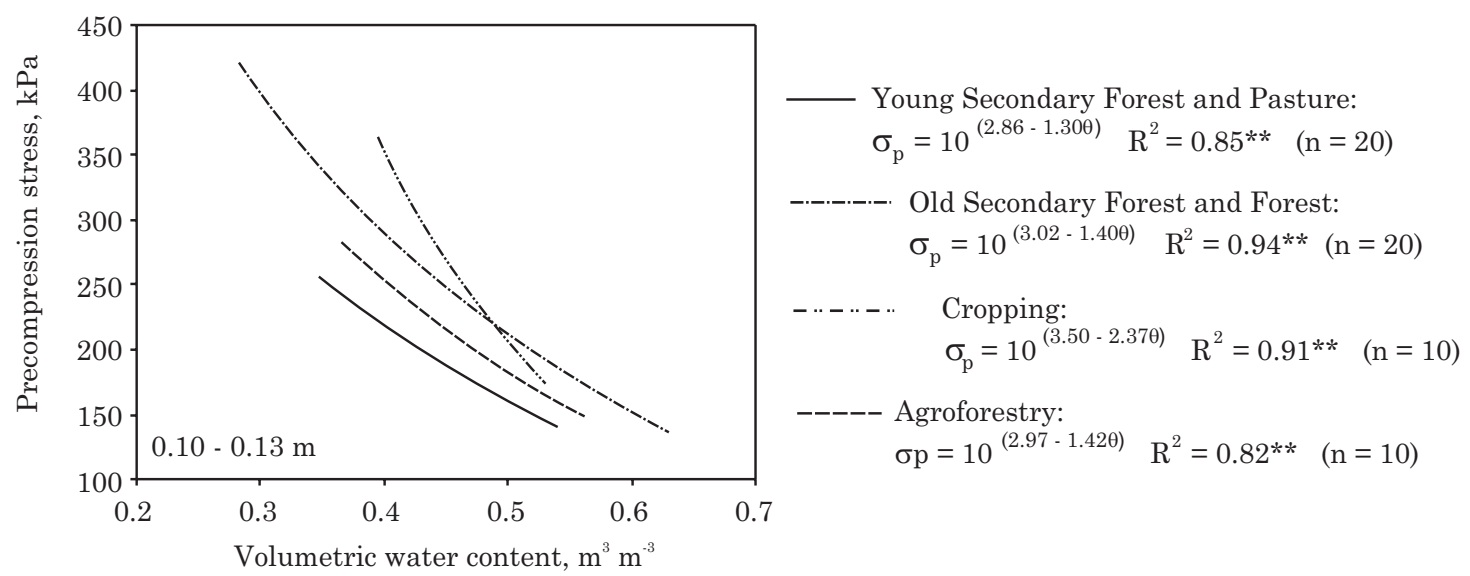

Figure 3. Load bearing capacity models for a Cambisol at $0.10-0.13 \mathrm{~m}$ depth under different land use systems.

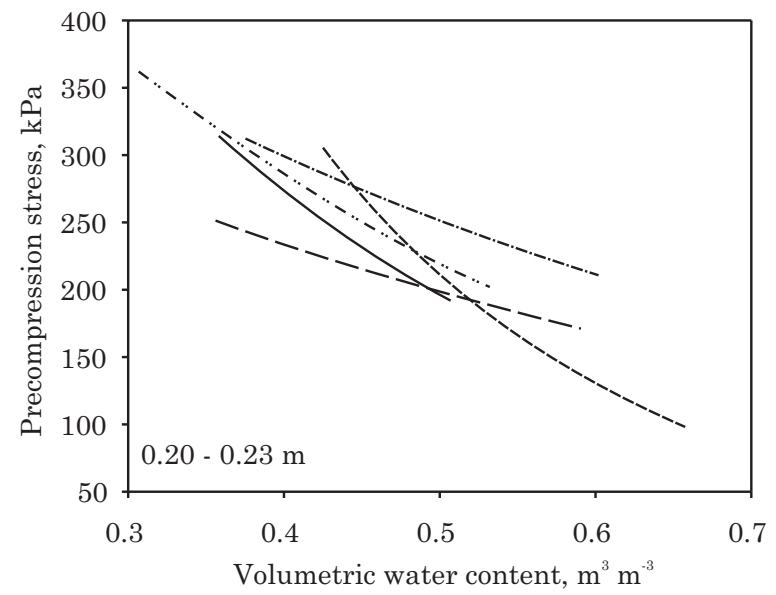

$$
\begin{aligned}
& \text { Young Secondary Forest: } \\
& \sigma_{\mathrm{p}}=10^{(3.00-1.40 \theta)} \quad \mathrm{R}^{2}=0.87^{* *} \quad(\mathrm{n}=10) \\
& \text { Old Secondary Forest: } \\
& \sigma_{\mathrm{p}}=10^{(2.78-0.75 \theta)} \mathrm{R}^{2}=0.71^{* *} \quad(\mathrm{n}=10) \\
& \text {-....... Forest and Pasture: } \\
& \sigma_{\mathrm{p}}=10^{(2.90-1.12 \theta)} \quad \mathrm{R}^{2}=0.87^{* *} \quad(\mathrm{n}=20) \\
& \text {----- Cropping: } \\
& \sigma_{\mathrm{p}}=10^{(3.39-2.13 \theta)} \mathrm{R}^{2}=0.93^{* *} \quad(\mathrm{n}=10) \\
& \text { - - Agroforestry: } \\
& \sigma_{\mathrm{p}}=10^{(2.65-0.70 \theta)} \quad \mathrm{R}^{2}=0.85^{* *} \quad(\mathrm{n}=10)
\end{aligned}
$$

Figure 4. Load bearing capacity models for a Cambisol at $0.20-0.23 \mathrm{~m}$ depth under different land use systems. 
system and well preserved in young secondary forest, cropping and agroforestry.

\section{LITERATURE CITED}

ABID, M. \& LAL, R. Tillage and drainage impact on soil quality I: Aggregate stability, carbon and nitrogen pools. Soil Tillage Res., 100:89-98, 2008.

AJ AYI, A.E.; DIAS J UNIOR, M.S.; CURI, N.; OKUNOLA, A.; SOUZA, T.T. \& PIRES, B.S. Assessment of vulnerability of Oxisols to compaction in the Cerrado region Brazil. Pedosphere, 20:252-260, 2010.

AJ AYI, A.E.; DIAS J UNIOR, M.S.; CURI, N. \& OLUFAYO, A.A. Soil color as simple indicator of load bearing capacity in Brazilian Oxisols. J. Ind. Soc. Soil Sci., 59:14-21, 2011.

ARAUJ O J UNIOR, C.F.; DIAS J UNIOR, M.S.; GUIMARÃES, P.T.G. \& PIRES, B.S. Resistência à compactação de um Latossolo cultivado com cafeeiro, sob diferentes sistemas de manejo de plantas invasoras. R. Bras. Ci. Solo, 32:2321, 2008.

ARAUJ O J UNIOR, C.F.; DIAS J UNIOR, M.S.; GUIMARÃES, P.T.G. \& ALCÂNTARA, E.N. Capacidade de suporte de carga e umidade crítica de um Latossolo induzida por diferentes manejos. R. Bras. Ci. Solo, 35:115-131, 2011.

ARAÚJ O, E.A.; LANI, J .L.; AMARAL, E.F.\& GUERRA, A. Uso da terra e propriedades físicas e químicas de Argissolo Amarelo distrófico na Amazônia Ocidental. R. Bras. Ci. Solo, 28:1-8, 2004.

ARKIN, G.F. \& TAYLOR, H.M. Modifying the root environment to reduce crop stress. 3.ed. St. J oseph, American Society of Agricultural Engineers, 1981. 407p.

ARVIDSSON, J . \& KELLER, T. Soil precompression stress. I. A survey of Swedish arable soils. Soil Tillage Res., 77:8595, 2004.

ARVIDSSON, J. Subsoil compaction caused by heavy sugar beet harvesters in southern Sweden I. Soil physical properties and crop yield in six field experiments. Soil Tillage Res., 60:67-78, 2001.

BLAKE, G.R. \& HARTGE, K.H. Bulk density. In: KLUTE, C., ed. Methods of soil analysis. Physical and mineralogical methods. 2.ed. Madison, American Society Agronomy, 1986a. Part 1. p.363-375. (Agronomy Monograph, 9).

BLAKE, G.R. \& HARTGE, K.H. Particle density. In: KLUTE, A., ed. Methods of soil analysis. Physical and mineralogical methods. 2.ed. Madison, American Society Agronomy, 1986b. Part 1. p.377-381. (Agronomy Monograph, 9).

BOWLES, J.E. Engineering properties of soils and their measurements. 3.ed. New York, McGraw Hill, 1986. 218p.

COELHO, M.R.; FIDALGO, E.C.C.; ARAÚJ O, F.O.; SANTOS, H.G.; SANTOS, M.L.M. \& PÉREZ, D.V. Solos das áreas-piloto do Projeto GEF BIOS (Conservation and sustainable management of below-ground biodiversity: Phasel ), Município de Benjamin Constant, Estado do Amazonas. Rio de J aneiro, Embrapa Solos, 2005. 158p. (Boletim de Pesquisa).
CORREA, J.C. \& REICHARDT, K. Efeito do tempo de uso das pastagens sobre as propriedades de um Latossolo Amarelo da Amazônia Central. Pesq. Agropec. Bras., 30:107-114, 1995.

DAY, P.R. Particle fractionation and particle size analysis. In: KLUTE, C. A., ed. Methods of soil analysis. Physical and mineralogical methods. Madison, American Society Agronomy, 1986. Part 1. p.545-567. (Agronomy Monograph, 9).

DIAS J UNIOR, M.S. \& PIERCE, F.J . A simple procedure for estimating precompression stress from soil compression curves. Soil Technol., 8:139-151, 1995.

DIAS J UNIOR, M.S. \& PIERCE, F.J . Revisão de literatura: O processo de compactação do solo e sua modelagem. R. Bras. Ci. Solo, 20:175-192, 1996.

DIAS J UNIOR, M.S.; FONSECA, S.; ARAUJ O J UNIOR, C.F. \& SILVA, A.R. Soil compaction due to forest harvest operations. Pesq. Agropec. Bras., 42:257-264, 2007.

DIAS J UNIOR, M.S.; SILVA, S.R.; SANTOS, N.S. \& ARAUJ O J UNIOR, C.F. Assessment of the soil compaction of two Ultisols caused by logging operations. R. Bras. Ci. Solo, 32:2245-2253, 2008.

EMPRESA BRASILEIRA DE PESQUISA AGROPECUÁRIA EMBRAPA. Centro Nacional de Pesquisas de Solos. Sistema brasileiro de classificação de solos. 2.ed. Rio de J aneiro, 2006. 306p.

FIDALGO, E.C.; COELHO, M.R.; ARAÚJ O, F.O.; MOREIRA, F.M.S.; SANTOS, H.G.; SANTOS, M.L.M. \& HUISING, J . Levantamento do uso e cobertura da terra de seis áreas relacionadas ao projeto "Conservation and sustainable management of below-ground biodiversity: Phase 1", município de Bejanmin Constant, (AM) (Land use and land cover survey in benchmark area of CSM-BGBD/ BiosBrasil Project: Phase 1, Benjamin Constant, Embrapa Solos, 2005. (Boletim de Pesquisa e Desenvolvimento, 71)

FIGUEIREDO, G.C.; SILVA, A.P.;TORMENA, C.A.; GIAROLA, N.F.B.; MORAES, S.O. \& ALMEIDA, B.G. Desenvolvimento de um consolidômetro pneumático: Modelagem da compactação, penetrometria e resistência tênsil de agregadosde solo. R. Bras. Ci. Solo, 35:389-402, 2011.

GLAB, T. \& KULIG, B. Effect of mulch and tillage system on soil porosity under wheat (Triticum aestivum). Soil Tillage Res., 99:169-178, 2008.

GYSI, M. Compaction of a Eutric Cambisol under heavy wheel traffic Switzerland: Field data and a critical state soil mechanics model approach. Soil Tillage Res., 61:133-142, 2001.

ISHAQ, M.; IBRAHIM, M.; HASSAN, A.; SAEED, M. \& LAL, R. Subsoil compaction effects on croppings in Punjab, Pakistan: II. Root growth and nutrient uptake of wheat and sorghum. Soil Tillage Res., 60:153-161, 2001.

J ONES, R.J .A.; SPOOR, G. \& THOMASSON, A.J . Vulnerability of subsoils in Europe to compaction: A preliminary analysis. Soil Tillage Res., 73:131-143, 2003. 
KÄMPF, N. \& CURI, N. Formação e evolução do solo (pedogênese). In: KER, J.C.; CURI, N.; SCHAEFER, C.E.R. \& TORRADO, P.V., eds. Pedologia: Fundamentos. Viçosa, MG, Sociedade Brasileira de Ciência do Solo, 2012. p.207-302.

LIPIEC, J .; KUE, J .; SLOWIÑSKA-J URKIEWICZ, A. \& NOSALEWICZ, A. Soil porosity and water infiltration as influenced by tillage methods. Soil Tillage Res., 89:210220, 2006.

MARTINS, P.C.C. Avaliação da sustentabilidade da estrutura de um Cambissolo sob diferentes sistemas de uso da terra na Amazônia Ocidental. Lavras, Universidade Federal de Lavras, 2009. 44p. (Tese de Mestrado)

MOSADDEGHI, M.R.; HEMMAT, A.; HAJ ABBASI, M.A. \& ALEXANDROU, A. Pre-compression stress and its relation with the physical and mechanical properties of a structurally unstable soil in central I ran. Soil Tillage Res., 70:53-64, 2003.

MULLER, M.M.L.; GUIMARÃES, M.F.; DESJ ARDINS, T. \& MITJA, D. The relationship between pasture degradation and soil properties in the Brazilian Amazon: A case study. Agric. E cosyst. Environ., 103:279-288, 2004.

MULLER, M.M.L.; GUIMARÃES, M.F.; DESJ ARDINS, T. \& MARTINS, P.F.S. Degradação de pastagens na Região Amazônica: Propriedades físicas do solo e crescimento de raízes. Pesq. Agropec. Bras., 36:1409-1418, 2001.

PACHECO, E.P. \& CANTALICE, J.R.B. Compressibilidade, resistência a penetração e intervalo hídrico ótimo de um Argissolo Amarelo cultivado com cana-de-açúcar nos tabuleiros costeiros de Alagoas. R. Bras. Ci. Solo, 35:403415, 2011.

PENG, X.H.; HORN, R.; ZHANG, B. \& ZHAOA, Q.G. Mechanisms of soil vulnerability to compaction of homogenized and recompacted Ultisols. Soil Tillage Res., 76:125-137, 2004.

SEVERIANO, E.C.; OLIVEIRA, G.C.; CURI, N. \& DIAS JUNIOR, M.S. Potencial de uso e qualidade estrutural de dois solos cultivados com cana-de-açúcar em Goianésia. R. Bras. Ci. Solo, 33:159-168, 2009.
SEVERIANO, E.C.; OLIVEIRA, G.C.; DIAS J UNIOR, M.S.; OLIVEIRA, L.F.C. \& CASTRO, M.B. Pressão de preconsolidação e intervalo hídrico ótimo como indicadores de alterações estruturais de um Latossol o e de um Cambissolo sob cana-de-açúcar. R. Bras. Ci. Solo, 32:1419-1427, 2008.

SEVERIANO, E.C.; OLIVEIRA, G.C.; DIAS J UNIOR, M.S.; CASTRO, M.B.; OLIVEIRA, L.F.C. \& COSTA, K.A.P. Compactação de solos cultivados com cana-de-açúcar: I Modelagem e quantificação da compactação adicional após as operações de colheita. Eng. Agríc., 30:404-413, 2010a.

SEVERIANO, E.C.; OLIVEIRA, G.C.; DIAS J UNIOR, M.S.; CASTRO, M.B.; OLIVEIRA, L.F.C. \& COSTA, K.A.P. Compactação de solos cultivados com cana-de-açúcar: II Quantificação das restrições às funções edáficas do solo em decorrência da compactação prejudicial. Eng. Agríc., 30:414-423, 2010b.

SIGMA PLOT. Scientific Graphing Software: Versão 8.0. San Rafael, J andel Corporation, 2002.

SILVA, A.R.; DIAS J UNIOR, M.S. \& LEITE, F.P. Camada de resíduo e pressão de preconsolidação de dois Latossolos. Pesq. Agropec. Bras., 42:89-93, 2007.

SILVA, A.R.; LIMA, J.M. \& DIAS J UNIOR, M.S. Efeito da adsorção de fosfato em parâmetros físicos e na compressibilidade de solos tropicais. R. Bras. Ci. Solo, 23:219-226, 1999.

SILVA, S.R.; BARROS, N.F. \& COSTA, L.M. Atributos físicos de dois Latossolos afetados pela compactação do solo. R. Bras. Ci. Solo, 10:842-847, 2006.

SNEDECOR, G.W. \& COCHRAN, W.G. Statistical methods. 8.ed. Ames, lowa State University Press, 1989. 503p.

SPOOR, G.; TIJINK, F.G.J.\& WEISSKOPF, P. Subsoil compaction: Risk, avoidance, identification and alleviation. Soil Tillage Res., 73:175-182, 2003.

TAYLOR, D.W. Fundamentals of soil mechanics. New York, J ohn Wiley \& Sons, 1948. 700p.

TAYLOR, H.M. Effects of soil strength on seedling emergence, root growth and cropping yield. In: BARNES, K.K.; CARLETON, W.M.; TAYLOR, H.M.; THROCKMORTON, R.I \& van den BERG, G.E., eds. Compaction of agricultural soils. Saint J oseph, ASAE, 1971. p.292-305. 